\title{
LENGTH OF GESTATION PERIODS OF HORSES AND PONIES BE- LONGING TO DIFFERENT BREEDS
}

\author{
H. BOS and G.J.W. VAN DER MEY \\ Vakgroep Zoötechniek, Yalelaan 17, Utrecht (The Netherlands)
}

(Accepted 21 September 1979)

\section{ABSTRACT}

Bos, H. and Van der Mey, G.J.W., 1980. Length of gestation periods of horses and ponies belonging to different breeds. Livest. Prod. Sci., 7: 181-187.

The mean gestation periods of mares belonging to different horse and pony breeds common in The Netherlands have been calculated using data from the birth registers of five stud-book societies. The following mean values have been determined: Fjord pony: 342.2; Haflinger pony: 341.3 ; Draught horse: 343.3 ; Shetland pony: 337.2 ; and Frisian horse: 337.7 days. The variation in the mean gestation period is greater in horses than in cows, sheep or pigs. Colts are carried a little longer than fillies. Differences between years are not significant, but differences between the various breeds have been determined. Shetland foals born before 1 June are carried longer than those born after 1 June. The gestation period for mares of this breed mated at 2 years, is significantly longer than for those mated at more than 2 years.

The length of the gestation period in horses is possibly affected by physiological factors other than those influencing the gestation period in some other farm animals.

\section{INTRODUCTION}

Length of gestation period is of great interest for economic reasons and also for identification of horses. Only the exact knowledge of the breed-specific gestation periods and their variation allows, for example, one to dispense with blood typing and thus to save costs. For this reason, an extension of these investigations on the relevant breeds of horses and ponies seems to be desirable.

The varying values found in the literature regarding the mean gestation periods of mares from different breeds are given in Table I. A comparison of breeds based on these data is not accurate because of the different research methods used and because the mean values usually refer to studies made within one particular breed. The data also show that the variation in the mean gestation period is great and that colts are carried longer than fillies.

Because registration of mating and the birth of the foals is done very systematically in The Netherlands, and because the number of thoroughbreds is sufficiently large, a comparative study into the mean gestation period was made on mares belonging to the following breeds: the Fjord pony, the Haflinger pony, the Dutch draught horse, the Frisian horse, and the Shetland pony. 
TABLE I

Mean gestation periods (days) of some breeds of horses and ponies (from the literature)

\begin{tabular}{|c|c|c|c|c|c|}
\hline \multirow[t]{2}{*}{ Breed } & \multicolumn{2}{|l|}{ Reference } & \multicolumn{3}{|l|}{$q+o$} \\
\hline & & & $n$ & $\bar{x}$ & $s$ \\
\hline Haflinger & $\begin{array}{l}\text { Di Lella et al. } \\
\text { Pajonovic }\end{array}$ & $\begin{array}{l}(1971) \\
(1965)\end{array}$ & $\begin{array}{l}1792 \\
4462\end{array}$ & $\begin{array}{l}341.0 \\
335.87\end{array}$ & $\begin{array}{l}17.0 \\
12.87\end{array}$ \\
\hline Draught horse & $\begin{array}{l}\text { Wussow and Hartwig } \\
\text { Uppenborn }\end{array}$ & $\begin{array}{l}(1953) \\
(1933)\end{array}$ & $\begin{array}{l}- \\
-\end{array}$ & - & $\begin{array}{l}- \\
-\end{array}$ \\
\hline Lippizaner & $\begin{array}{l}\text { Staffe } \\
\text { Mauch }\end{array}$ & $\begin{array}{l}(1935) \\
(1937)\end{array}$ & - & $\begin{array}{c}- \\
334.26\end{array}$ & $\overline{9.56}$ \\
\hline Trakehner & $\begin{array}{l}\text { Flade and Frederich } \\
\text { Uppenborn }\end{array}$ & $\begin{array}{l}(1963) \\
(1933)\end{array}$ & $\begin{array}{l}311 \\
-\end{array}$ & $\begin{array}{c}336.75 \\
-\end{array}$ & $\begin{array}{c}15.60 \\
-\end{array}$ \\
\hline Nonius & $\begin{array}{l}\text { Mauch } \\
\text { Zavrnick and Ilančic }\end{array}$ & $\begin{array}{l}(1937) \\
(1941)\end{array}$ & $\begin{array}{r}432 \\
1629\end{array}$ & $\begin{array}{l}335.99 \\
328.88\end{array}$ & $\begin{array}{c}10.50 \\
9.487\end{array}$ \\
\hline Araber & Mauch & $(1937)$ & 521 & 337.44 & 10.39 \\
\hline
\end{tabular}

Studies were also made into whether sex differences occur and whether the year of birth, month of birth of age of the mare influence the period of gestation.

\section{MATERIALS AND METHOD}

Data concerning foals born in 1969,1970 and 1971 were studied from records belonging to the stud-book societies of the above-mentioned breeds. For the Shetland pony, only data from 1971 were available. The following data were noted for each foal: the date of mating of the mother, date of birth, sex, stud-book numbers and ages of the parents. Stillborn foals and foals whose mothers had been with the stallion for some time or who had mated several times during the same heat period were not considered.

The term gestation period is understood as the interval between last mating and parturition; in determining this interval, the date of parturition is counted but not the date of mating. When calculating the mean gestation period only 'normal' gestation periods are used. By 'normal' we mean gestation periods of $\leqslant 375$ days. Mean gestation periods and their variations were calculated using data from 7102 foals. Differences between group averages were tested statistically.

\section{RESULTS}

The results of a comparative study of breeds are given in Table II. Because no significant differences were found between the years, the means in this 


\begin{tabular}{|c|c|c|c|c|c|}
\hline \multicolumn{3}{|l|}{ \& } & \multicolumn{3}{|l|}{$\sigma$} \\
\hline$n$ & $\bar{x}$ & $s$ & $n$ & $\bar{x}$ & $s$ \\
\hline - & - & - & - & - & - \\
\hline 2243 & 335.42 & 12.81 & 2206 & 336.22 & 12.88 \\
\hline 10058 & 335.88 & - & 9111 & 337.33 & - \\
\hline 82 & 332.60 & 9.33 & 84 & 333.37 & 9.53 \\
\hline 133 & 337.0 & - & 140 & 337.8 & - \\
\hline 130 & 332.99 & 9.27 & 122 & 334.81 & 9.42 \\
\hline - & - & - & - & - & - \\
\hline 3849 & 331.91 & 9.18 & 3787 & 333.45 & 9.40 \\
\hline 207 & 335.01 & 10.60 & 225 & 336.76 & 10.29 \\
\hline 835 & 327.91 & - & 794 & 329.89 & - \\
\hline 261 & 336.97 & 10.01 & 260 & 339.54 & 10.34 \\
\hline
\end{tabular}

TABLE II

Mean gestation periods (days) of some breeds of horses and ponies

\begin{tabular}{|c|c|c|c|c|c|c|c|c|c|}
\hline \multirow[t]{2}{*}{ Breed } & \multicolumn{3}{|l|}{$q+0$} & \multicolumn{3}{|l|}{ q } & \multicolumn{3}{|l|}{8} \\
\hline & $n$ & $\bar{x}$ & $s$ & $n$ & $\bar{x}$ & $s$ & $n$ & $\bar{x}$ & $s$ \\
\hline Fjord & 1313 & 342.3 & 11.4 & 688 & 341.8 & 11.1 & 625 & 342.8 & 11.8 \\
\hline Haflinger & 1034 & 341.3 & 11.3 & 593 & 341.2 & 11.4 & 441 & 341.5 & 11.2 \\
\hline Draught horse & 2002 & 343.2 & 10.1 & 1242 & 342.5 & 10.1 & 760 & 344.3 & 10.0 \\
\hline Shetland & 2327 & 337.2 & 12.4 & 1520 & 336.9 & 12.4 & 807 & 337.7 & 12.4 \\
\hline Frisian & 426 & 337.7 & 9.6 & 236 & 337.1 & 9.3 & 190 & 338.4 & 9.9 \\
\hline
\end{tabular}

\section{TABLE III}

Results of the statistical testing of breed and sex differences

Breed differences Sex differences
(2)
(3)
(4)
(5)

$\begin{array}{lllll}\text { (1) Fjord } & * & * * * & * * * & \text { n.s. } \\ \text { (2) Haflinger } & * * * & * * * & * * * & \text { n.s. } \\ \text { (3) Draught horse } & & * * * & * * * & * * * \\ \text { (4) Shetlander } & & & \text { n.s. } & \text { n.s. } \\ \text { (5) Frisian } & & & & \text { n.s. }\end{array}$

$*=P<0.05 .{ }^{*}=P<0.01 . * * *=P<0.001$. n.s. $=$ not significant. 
table refer to the 3 years taken as a whole. However, breed and sex differences were apparent, and the results of the statistical testing of these differences are given in Table III.

\section{DISCUSSION}

\section{Mean gestation period}

In a previous investigation in The Netherlands into the mean gestation period of the Dutch horse, the Draught horse, the Frisian horse and the Shetland pony, Hendrikse (1972) calculated means of $340,339,337$ and 338 days, respectively. The data concerning the Frisian horse and the Shetland pony agree well with the results of our investigations; this is not so for the mean gestation period of the Draught horse. The difference here is a good 4 days. In general, the mean gestation period of horses is estimated at 11 months. Our investigations show that it is better to reckon on 11 months +1 week for the Fjord horse, the Haflinger pony and the Draught horse.

\section{Variations}

According to the literature and data from Table II, there are large variations in the gestation period of horses. These variations are less in other farm animals. This has been shown in an investigation by Banerjee-Schotsman (1964) who found a variation coefficient of 1.5 in cows. According to Prud'hon et al. (1970) this coefficient is 1.6 for sheep, and according to Cox et al. (1964) it is 1.4 for pigs. Our investigations show variation coefficients of $2.8-3.7$.

Because the variation in the mean gestation period in horses is greater, it can be concluded that the length of their gestation period is influenced by physiological factors other than those in influencing cows, sheep and pigs.

Flade and Frederich (1963) distinguish the ways in which an embryo develops by dividing the mammals into three groups, the first group being those animals where the embryo develops smoothly without interruption (e.g. cows, sheep, pigs). Then there are those in which the development of the embryo is interrupted at least once; for example 'latente stadia' in deer. This is known as a 'prolonged gestation period' in The Netherlands; the long gestation period of 9 months for a deer mated in the summer compared with 5 months for one mated in the autumn. Finally, equines are mentioned separately as a third group. The reason they did this is not given, but it was probably because there may be a seasonal influence on the gestation period of equines.

\section{Sex differences}

Mauch (1937), Pajanovic (1965) and Uppenborn (1933) found significantly longer gestation periods for colts. Flade and Frederich (1963), Howell and Rollins (1951), Jöchle (1957), Di Lella (1971) and Staffe (1935) could not show any sex differences. 
Our investigations show only significantly longer gestation periods for draught horse colts (Table III).

\section{Breed differences}

Only Flade and Frederich (1963) found any significant difference between the breeds with the exception of the Frisian horse and the Shetland pony.

\section{Influence of the month of birth}

According to Howell and Rollins (1951), Upperborn (1933) and Wussow and Hartwig (1953), the gestation period for foals born in January, February, March, April or May, is somewhat longer compared with the mean gestation period calculated over the whole year. These data have been applied to our material relating to Shetland ponies. The gestation periods of 2327 Shetland ponies were studied and divided into three groups:

(1) 348 foals born in January, February, March or April; mean gestation period 338.5 days.

(2) 1190 foals born in May; mean gestation period 339.2 days.

(3) 789 foals born in June, July, August or September; mean gestation period 333.4 days.

The difference between the mean gestation period for foals born in the period from January to May inclusive and those born in the period from June to September inclusive is significant $(* *)$.

\section{Influence of the mare}

There is no agreement on the relationship between the age of the mare and the length of her gestation period. Longer mean gestation periods have been determined for older mares by Flade and Frederich (1963) and for younger mares by Mauch (1937) and Pajanovic (1965). In these investigations the groups of young mares ( $\leqslant 4$ years) and older mares ( $\geqslant 10$ years), are small. Staffe (1935) states that primiparae usually have shorter gestation periods than multiparae.

Our data show 286 Shetland pony mares who have their first foal at 3 years. The mean gestation period for these mares is 338.7 days. The group of 2041 mares who foal at more than 3 years has a mean gestation period of 336.9 days. This is a significant difference $\left({ }^{*}\right)$. There are no significant differences when the mean gestation period of a group of 316 mares which foal at 4 years is compared with groups of mares foaling at $5,6,7,8$ years or older.

\section{Other influences}

The impression gained by horse-breeders that a certain mare foals every year before the calculated parturition date rather than after, indicates differ- 
ences have a family character. Further research into variations in the gestation period between mares and families would be beneficial.

\section{REFERENCES}

Banerjee-Schotsman, I., 1964. A Study Concerning Gestation Period in Cattle. Dissertation, University of Utrecht, $96 \mathrm{pp}$.

Cox, D.F., 1964. Genetic variation in the gestation period of swine. J. Anim. Sci., 23: $746-751$.

Di Lella, T., De Franciscus, G., Pitaro, E. and Zurlo, G., 1971. Su alcune statistiche vitali del cavallo Avelignese allevato nel mezzogiorno d'Italia. Atti. Soc. Ital. Sci. Vet., 25: 335-338.

Flade, J.E. and Frederich, W., 1963. Beitrag zum Problem der Trächtigkeitsdauer und zu ihrer faktoriellen Abhängigkeit beim Pferd. Arch. Tierz., 6: 505-520.

Hendrikse, J., 1972. Draagtijden van Nederlandse paardenrassen. Tijdschr. Diergeneeskd., 97 : $477-480$.

Howell, C.E. and Rollins, W.C., 1951. Environmental sources of variation in the gestation length of the horse. J. Anim. Sci., 10: 789-796.

Jöchle, W., 1957. Zur Dauer der Tragzeit und der Geschlechtsverteilung beim Pferd. Züchtungskunde, 29: 303-305.

Mauch, A., 1937. Untersuchungen über die Trächtigkeitsdauer der Stuten. Z. Tierzücht. Züchtungsbiol., 29: 31-42.

Pajanovic, R., 1965. Die Auswirkung der Umwelt auf die Trächtigkeitsdauer des Tiroler Haflingerpferdes. Z. Tierzücht. Züchtungsbiol., 82: 364-376.

Prud'hon, M., Desoignes, H. and Donoy, I., 1970. Results of six years breeding at Arles Merino ewes on the Merle-Estate. IV: Duration of pregnancy and birthweight of lambs. Ann. Zoötechn., 19: 439-454.

Staffe, A., 1935. Weitere Untersuchungen über die Trächtigkeitsdauer bei Lippizanern. Z. Tierzücht. Züchtungsbiol., 31: 79-88.

Uppenborn, W., 1933. Untersuchungen über die Trächtigkeitsdauer der Stuten. Z. Tierzücht. Züchtungsbiol., 29: 1-27.

Wussow, W. and Hartwig, W., 1953. Untersuchungen über die Trächtigkeitsdauer und die Verteilung des Geschlechtsverhältnisses in den verschiedenen Jahreszeiten beim Kaltblutpferd in Sachsen-Anhalt. Tierzucht, 7: 196-200.

Zavrnick, F. and Ilančic, D., 1941. Ueber die Trächtigkeitsdauer unserer Noniuspferderasse. Vet. Arh., 10: 405-424.

\section{RÉSUMÉ}

Bos, H. et Van der Mey, G.J.W., 1980. Durée de gestation des juments de différentes races de chevaux et de poneys. Livest. Prod. Sci., 7: 181-187 (en anglais).

La durée moyenne de gestation des juments de différentes races de chevaux et de poneys fréquentes aux Pays Bas a été calculée à partir des régistres de naissances de cinq stud-books. On a obtenu les valeurs suivantes: poney Fjord: 342,2 jours; poney Haflinger : 341,3 ; cheval de trait : 343,3 ; poney de Shetland : 337,2 ; cheval Frison : 337,7 . La variation de la durée moyenne de gestation est plus élevée chez les chevaux que chez les bovins, les ovins et les porcs. Les poulains sont portés un peu plus longtemps que les pouliches. Les différences entre années ne sont pas significatives. Les jeunes Shetland nés avant le ler juin sont portés plus longtemps que ceux nés après. La durée de gestation est significativement plus élevée pour les femelles Shetland saillies à 2 ans que pour celles saillies à plus de 2 ans.

La durée de la gestation des chevaux est peut être plus modifiée par d'autres facteurs physiologiques que ceux influençant la durée de la gestation d'autres espèces d'animaux domestiques. 


\section{KURZF ASSUNG}

Bos, H. und Van der Mey, G.J.W., 1980. Tragezeiten von Stuten verschiedener Pferde- und Ponyrassen. Livest. Prod. Sci., 7: 181-187 (in Englisch).

Die durchschnittlichen Tragezeiten von Stuten verschiedener Pferde- und Ponyrassen, die in den Niederlanden verbreitet sind, wurden anhand von Daten der Geburtsregister aus den Gestütbüchern von 5 Zuchtverbänden errechnet. Folgende Mittelwerte wurden bestimmt: Fjordpferd : 342,2; Haflinger: 341,$3 ;$ Zugpferd: 343,3 ; Shetlandpony: 337,2 und Friesisches Pferd: 337,7 Tage. Die variation in der durchschnittlichen Tragezeit ist bei Pferden grösser als bei Kühen, Schafen oder Schweinen. Die Tragezeit für Hengstfohlen ist etwas länger als für Stutfohlen. Die Unterschiede zwischen den Jahren sind nicht signifikant, aber es wurden Unterschiede zwischen den verschiedenen Rassen festgestellt. ShetlandFohlen, die vor dem 1. Juni geboren werden, werden länger ausgetragen als solche, die nach dem dem 1. Juni geboren werden. Die Tragezeit für Stuten dieser Rasse, die mit 2 Jahren belegt werden, ist signifikant länger als für Stuten, die mit mehr als 2 Jahren belegt werden.

Die länge der Tragezeit bei Pferden wird möglicherweise nicht von denselben physiologischen Faktoren beeinflusst wie die Tragezeit bei einigen anderen landwirtschaftlichen Nutztieren. 